\title{
Are Independent and Liberal Women Villains?
}

\author{
Saleem Abbas \\ Independent Researcher, Clemson, SC, USA \\ E: saleemabbas.fcc@gmail.com
}

\author{
Article Info: \\ Received 19 March 2018 \\ Accepted 13 June 2018 \\ Published 16 July 2018 \\ DOI: https://doi.org/10.12973/ojemt/2662
}

This paper unpacks the perpetuation of negativity in liberal and modern female roles telecast by Pakistani Urdu TV drama serials. These dramas relay an implicit message that a woman cannot be a successful professional and a good wife or mother at the same time. The majority of contemporary TV dramas constantly present liberal, bold, and independent females in negative roles i.e., villains, anti-heroines and unsuccessful persons. Whereas leading positive roles appear to be traditional and conformed to conventions. Constantly, repeated negative female images and stereotypical patterns through TV dramas tend to impinge upon viewers. Thus, I employ the framework of social cognitive theory to comprehend the findings and examine the implications of these negative female images. This paper examines forty female roles appeared in five popular Pakistani Urdu TV drama serials telecast during the period of 2012-2016 and discusses the ways in which stereotypes are conferred to the negative female roles in these serials. By using the methodology of thematic analysis, I argue that by associating female negative roles with the impression of modernity, boldness, and liberalism, these drama serials indirectly reinforce conventional and subservient attitudes for women. Moreover, this type of portrayal in TV drama serials not only reinforces the passivity and subordination for females, but also reduces the prospects of diversity, openness, and acceptance of an independent and progressive approach of women in Pakistan.

Keywords: gender inequality, Pakistani TV dramas, women portrayal, negative roles

\section{INTRODUCTION}

The current report of World Economic Forum (2017) reveals that the situation of gender equality is quite grim in Pakistan. According to the report, the country ranks $143^{\text {rd }}$ among 144 countries; also, Pakistan is at the bottom among other countries in South Asia. As women make up half of the country's population, the issues related to their portrayal and representation are very important to study. In order to explicate the representation of women in the country's popular media, I choose the genre of dramas in visual communication and analyze the depiction of women in negative roles only. TV drama has always been a popular source of entertainment in the media landscape of Pakistan. During the heydays of Pakistan Television (PTV), the prime time of TV (known for the broadcast of TV drama) would empty the roads of big cities. Although the outset of different TV channels (through cable network) and the expanding availability of social media 
have affected the popularity of this genre, the drama has been able to retain popularity among the majority of Pakistanis (Hasan, 2000). Thus, the analysis of women representation in the negative roles of dramas brings forth the issues of continuation in women stereotyping.

In this paper, I identify that Pakistani drama serials implicitly portray women in stereotypical ways. On one hand these dramas seem to emphasize women empowerment and on the other hand, the audience are exposed to the negative coverage of progressive and independent women. By using the method of thematic analysis, I study 129 episodes of 5 popular Urdu drama serials, all of which aired during the period of five years (i.e., 2012-2016). I examined dialogues and visual patterns of 40 different female roles to accomplish the following research goals:

(a) To examine the attributes of female negative roles (i.e., villains, anti-heroines, etc.).

(b) To identify the stereotypes associated with independent, liberal and rich women.

(c) To identify the ways by which the selected dramas present conventionality and submissiveness as an ideal female attribute.

\section{Portrayal of Women and Pakistani Urdu Drama Serials}

Television has the potential to influence its viewers' thinking patterns (Riddle, 2009). It serves as one of the motivational factors to inculcate social values and the roles of women in the family structure and society. In this context, observational learning and information processing theories provide a supportive perspective for understanding the influence of television. Bandura (2009), mentioned that people can model roles and behaviors seen on television via observational learning. Observational learning is a form of social learning which only needs a social model like teacher, parents, friends or any figure of the society in your surroundings. With the advent of television and digital media, now it is easy to observe all social models on screen. Bandura (1971), explains that in social situations people often learn much more very swiftly by observing the behaviors of others; they often join powerful, competent, prestigious models that leads to more positive consequences. Similarly, information processing theory argues that "the individuals who watch television, use various cognitive schemas to organize the observed phenomena" (Pehlke, Hennon, Radina, and Kuvalanka, 2009). Often the new information is considered in a way that fits with previously held beliefs. In other cases, the schema is modified to accommodate new information. "These schemas are formed and modified throughout life; media serves as a likely influence, as the previously held schema guides interpretation of encounters with...TV characters" (Lemish, 2007, p. 102). As Pakistani TV dramas are one of the popular genres of visual communication in the country, in the light of above theories, one can argue that these drams tend to affect audience heavily and play a significant role in the maintenance of status quo. Thus, the analysis of women portrayal in drama serials in the contemporary context merits investigation.

The period of the late 70s up to early 90s is considered the golden period of Pakistani dramas. Pakistan Television produced many super hit dramas serials like Waris, Dhoop Kinare, Tanhayan, Jangal, Marvi, Jangloos etc. All of these productions are famous for their strong stories, characterization, and direction. A long history of autocracy in the past Pakistani governments and a controlled media environment has led towards the negligence of egalitarian trends and their coverage. Issues of gender equality could not gain proper space in Pakistani mainstream media. In the 1980s, the country was under the influence of the pan-Islamic ideology of religious forces. As mentioned by Coll, S. (2009), that "the military dictator and cold warrior, Zia-ul-Haq who led the country under his 'Islamaization' thought transformed the whole culture of the society" (p. 98). One can see the reflection of the same culture in Pakistani drama serials produced during and right after Islamization period. Female representation in those dramas is quite traditional and conventional (Kothari, 2005, p. 298). Roles of affectionate mothers, domestic obedient housewives, religious, innocent and naïve sisters who are ready to sacrifice themselves 
on family traditions are common in these dramas. Majority of female characters are presented in submissive and passive roles and the element of societal patriarchy was glamorized (Hussain, 1996). In the late 90s, with the influx of satellite channels and cable TV, Pakistani dramas lost their popularity among viewers.

Before I delve into the exploration of negative female roles in drama serials, it is important to review relevant literature on female representation in media. There are several studies that examine gender biases in media (McNeil, 1975; Pehlke, Hennon, Radina, and Kuvalanka, 2009; Gul, 2017). Similarly, several research projects highlight the depiction of women in stereotypical roles in movies, television programs, and print media (Gerbner, 1979; O'Rorke, 2006; Hermes, 2007; Collins, 2011; Coombo \& Davis, 2013;). After reviewing 29 articles in the two special issues of Sex Roles, Collins (2011) mentioned that in a plethora of media content, women are underrepresented and they are commonly portrayed in traditional stereotyped roles i.e., nonprofessional, housemakers, wives or parents, and sexual gatekeepers (p. 290).

The situation of women portrayal in Pakistani visual media does not seem to be different from the aforementioned scenario. According to Kothari (2005), the women representation in Pakistani visual media particularly in television dramas varies in different political regimes. The proliferation of private television channels since 2002, brought a revival of Pakistani Urdu drama industry. PTV Home, Hum TV, Geo, Express Entertainment, Urdu1 and ARY Digital are the main entertainment channels which have specified themselves for the drama production. Many of their blockbuster productions shake the diasporic Pakistani drama lovers (Boone, 2014); (Shafiq, 2014); These channels produce many popular TV dramas, most of them discuss issues of gender discrimination and women rights. Contemporary period of Pakistani drama production is considered a revival of this industry (Ghai, 2014; Boone, 2014). They are scoring good rating on the popularity graphs. A quality change can be seen in the composition of modern Urdu drama serials; and also there is a significant shift in the portrayal of women's issues too (Saeed, 2016). Social issues are the focal point of new dramatists. Although they highlight some women issues, the gender representation is still a big issue in these dramas. It is generally considered that Pakistani media does not depict a candid picture of females' diverse lives. Their progress is always seen through a stereotypical lens. "Strong professional women are often cast as villains in visual media" (Talib \& Idrees, 2012, p. 32). Especially in TV dramas, the portrayal of a successful professional woman is still questionable. In the light of the above-mentioned studies, it appears that Pakistani media present dubious ideas in terms of women representation. Generally, it wavers between the active and passive roles of women. While the majority of Pakistani TV programs endorse women empowerment, there are some programs that promote dependency. There appears to be a dearth of an in-depth study of negative female roles telecast in modern Pakistani drama serials. Thus, this paper is an endeavor to address that area.

\section{Methodology}

This study discusses in details the ways in which women stereotypes are conferred through the aforementioned drama serials. By a thematic analysis approach, I contend that through the portrayal of archetypal negative roles, Pakistani dramas are perpetuating the anti-feminist approach of male chauvinism and gender inequality. I studied the following research questions:

1. Do modern Pakistani Urdu TV drama serials depict independent, rich, and modern females as villains, anti-heroines or abortive persons?

2. In terms of matrimonial life, do Pakistani dramas tend to strengthen (explicitly/implicitly) liberal, independent, and non-religious attitudes as a disqualification of females?

3. Do these dramas tend to associate untrustworthy, Neurotic, suspicious, emotional, Impatient, materialistic, and less courteous behavior with independent and modern (liberal, bold, educated) females? 
4. In the comparison of conventionality/submissiveness versus modern/independent, what kind of woman is shown as a man's choice of marriage?

For this purpose, I analyzed 40 female roles from five contemporary popular Pakistani Urdu TV drama serials of past five years (2012-2016). In order to have a representative sample, I chose one popular drama serial from each year. These dramas include Man Mayal (Affection) (2016), Zid (Obstinacy) (2015), Mere Mehrban (My Benefactor) (2014), Zindagi Gulzar Hay (Life is a Rose Garden) (2013), and Hamsafar (Companion) (2012). These dramas score 8 and above on a scale of 10 at the Internet Movie Database (IMDb) ${ }^{1}$ rating scale. All the selected dramas were telecast by Hum TV and were produced by four different private production companies. Table 1 shows the production details of the selected drama serials.

\begin{tabular}{llllll}
\hline Year & Drama Serials & $\begin{array}{l}\text { Female } \\
\text { Roles }\end{array}$ & $\begin{array}{l}\text { No. } \\
\text { Episodes }\end{array}$ & ofIMDb Rating Production Co. \\
\hline 2012 & Hamsafar & 8 & 23 & 9 & MD Productions \\
\hline 2013 & Zindagi Gulzar Hai & 9 & 26 & 9 & Moomal Productions \\
\hline 2014 & Mere Meherban & 9 & 28 & 8.4 & $7^{\text {th }}$ Sky Entertainment \\
\hline 2015 & Zid & 7 & 19 & 8 & G.M Productions \\
\hline 2016 & Man Mayal & 7 & 33 & 8.2 & MD Productions \\
\hline
\end{tabular}

Table 1: Drama Production Details

This study discusses in details the ways in which women stereotypes are conferred through the aforementioned drama serials. By a thematic analysis approach, I contend that through the portrayal of archetypal negative roles, Pakistani dramas are perpetuating the anti-feminist approach of male chauvinism and gender inequality. I studied the following research questions:

1. Do modern Pakistani Urdu TV drama serials depict independent, rich, and modern females as villains, anti-heroines or abortive persons?

2. In terms of matrimonial life, do Pakistani dramas tend to strengthen (explicitly/implicitly) liberal, independent, and non-religious attitudes as a disqualification of females?

3. Do these dramas tend to associate untrustworthy, Neurotic, suspicious, emotional, Impatient, materialistic, and less courteous behavior with independent and modern (liberal, bold, educated) females?

4. In the comparison of conventionality/submissiveness versus modern/independent, what kind of woman is shown as a man's choice of marriage?

I carefully screened 129 episodes of these dramas in total and by following the pattern of Stacy Smith (2016) I chose female characters according to the following three point criteria:

1) A female character appeared on the screen and spoke at least one dialogue to make sure that she is a living character;

2) Other characters refer to the same female characters;

3) The character's name appears in the closing credits of the drama serial.

By following these criteria, I obtained 40 female characters in total and analyzed the relevant scenes. After reviewing the characteristics of the 40 female roles in 2,734 scenes, I considered 13 characters who are associated with negative attributes (i.e., vengefulness, rudeness,

\footnotetext{
${ }^{1} \mathrm{IMDb}$ maintains the online database for movies, television, and video games and is owned by IMDb.com, Inc., a subsidiary of Amazon.
} 
deceitfulness, hostility, meanness, and impatience, etc.). These 13 negative female characters showed their presence in 2,078 scenes. Besides the transcription of scenes, a screen shot of each scene is also taken for the close analysis of each character's outlook and back drops. The 13 selected negative female characters are further divided into three strata of (i) villains, (ii) antiheroines, and (iii) abortive persons (on the basis of operational definitions). I thoroughly analyzed the appearances and attributes of abovementioned female negative characters and found many similarities, which I shall discuss in a moment. The categories that I included in the coding frames are: professional, modern, liberal, bold, educated, non-religious, vengeful, neurotic, rude, deceitful, hostile, mean, materialistic, and impatient. In this paper, I have also incorporated relevant dialogues of characters to support my arguments. As these dramas are in the Urdu language, so I have translated the dialogues in English.

\section{Operational Definitions of Coding Characteristics}

Villain. A shrewd female character who is portrayed as a termagant and vitriolic woman. For instance, if a character always appears in a hostile behavior; or is problematic for other characters; or she opposes protagonists out of jealousy by using unfair means; such a character is considered as a villain.

Anti-heroine. The central female character who fails to achieve hero's love; or a protagonist female character who has a love affair with hero and she wants to marry him but finally hero marries another girl, then the central female character is marked as anti-heroine.

Abortive Person. The success of the character is measured by the achievement of her central goal in the story. A female character is marked abortive or unsuccessful person if she fails to achieve the central goal in the drama, regardless of attaining any other material benefits. For example, in drama, if a girl marries but ends up in divorce; or if a girl wants to be a doctor but her circumstances do not allow her to receive medical education; such character is taken as unsuccessful. Similarly, if the mother is shown as responsible for her children's broken marital relation and their immoral behavior and upbringing, then the mother is also marked as an abortive person.

Professional. Any female character who is depicted as a working woman either to support her family or as a pastime. Working at home is not included in this category.

Modern. This category applies if the character wears westernized dresses or fashionable /trendy clothes, has a haircut/style, does not use dupatta or head-covering, and uses English words in her dialogues.

Liberal. A woman who exercises and enjoys maximum possible individual freedom within her circle(s). For example, she takes decisions about her education, her career, her clothing, and her relations.

Bold. This applies if the character is non-submissive; does not feel hesitation talking to anyone (particularly males); questions authority of parents and other male members of the society.

Rich. This applies if the character is shown to be rich; if she is shown in expensive outfits and jewelry; possesses a car and lives in a big house with servants (i.e. cook, gardener, made-servant, driver etc.).

Educated. This category applies if a character is portrayed as a student, or the character is a professional woman and working in an office where a certain qualification is required. All verbal or non-verbal indication is taken as a proof which can establish her as an educated person (for example, mounted certificates on walls, or a dialogue of any character mentioning her qualifications, etc.). 
Non-religious. A character is taken as non-religious if she makes fun of religious people and clerics; prefers westernized dress upon traditional one, and does not appear with dupatta (stole).

Vengeful. The character is marked vengeful if she never gives up on a grudge and feels or shows a desire for revenge.

Neurotic. The character is included in the category if she is emotionally unstable, hypersensitive or mentally obsessed with something.

Rude. This category is applied if a character shows impolite behavior or becomes discourteous to others in her conversation. Her voice tone becomes loud or she is always shown to be critical of others.

Deceitful. The character is categorized as deceitful if she has the disposition to deceive or give a false impression in her daily affairs, or she appears to have unfair dealings or does not fulfill her promises and commitments.

Hostile. Any character who is quarrelsome and never do anything without a fuss, or provokes aggression with her words or action.

Mean. In this category all those characters are included who are unfriendly to others and show malicious behavior.

Materialistic. If the character is excessively concerned with material possessions (e.g., car, house, jewelry, dresses, cash etc.) or monetary benefits and does not consider moral values, such character is included in this category.

Impatient. This category applies when any character is shown to be in haste without thinking/considering the consequences of her action, or if she shows the immature behavior of intolerance.

\section{Negative Roles, Characteristics, and Narrative}

For most TV dramas, conflict is an important element. There are a number of ways whereby these dramas generate a conflict, or a battle of good and evil, or right and wrong. Among the most commonly opted styles include the difference of opinion, the clash of interest, professional jealousy, ideological rift, and suspicious nature, etc. According to the Merriam Webster dictionary, the element of conflict is defined as "a composition in verse or prose intended to portray life or character or to tell a story usually involving conflicts and emotions through action and dialogue". As the main evil character of a drama is called villain, this character (he or she) is an antagonist who always casts negative effects on other characters. Villain also constitutes an important evil agency in the plot (Dictionary.com, n.d.). Sometimes the complexity of story does not easily reveal the nature of its character(s); a character that seems good-natured turns out to be a villain at the end.

In modern Pakistani television drama serials, mostly stories consist of compound plots in which writers carry side-tracks along with the main storyline. In this way, more than one negative characters can be found in a serial. Table 2 provides a brief overview of negative female roles. 


\begin{tabular}{llll}
\hline Dramas & Year & Character & Negative Role \\
\hline Man Mayal & 2016 & Kookie & Villain \\
\hline Zid & Jenna & Anti-heroin \\
\hline Mere Mehrban & 2015 & Zee & Anti-heroin \\
\hline & Shaista & Villain \\
\hline & Muskan & Abortive person \\
\hline Zindagi Gulzar Hay 2013 & Naima & Abortive person \\
\hline & Iraj & Abortive person \\
\hline Hamsafar & Sara & Abortive person \\
\hline & Ghazala & Abortive person \\
\hline & Asmara & Anti-heroin \\
\hline & Farida & Villain \\
\hline
\end{tabular}

Table 2: Negative Female Roles

\section{Villains}

Out of five, three dramas portray women as villains (see 'Kookie' in Man Mayal, 'Shaista' in Mere Meherban, and 'Farida' in Hamsafar). These villains reflect negativity in a number of ways; some examples include being vengeful, proud, arrogant, loud and dominating as well as suspicious, cunning, and possessive. Moreover, discrimination, cheating, biases and conspiracies are also the part of their personalities. At the same time, these women are shown to be liberal, modern, independent, educated, rich, and bold.

Let us review the negative characters in these dramas one by one. In the drama serial Man Mayal, the character of 'Kookie' is a young, educated, modern and beautiful wife of Ifti (a friend and employer of hero, Salahuddin). Although Kookie lives in a big bungalow and belongs to a rich class, her aggressive individuality and an authoritarian attitude support the common stereotyping of the same class. She is shown as a mean woman who does not want to entertain any guest and does not trust anyone. Kookie's egocentricity is divulged in her dealings with Rehman (Ifti's old father, who transfers all his money and property to his son.) The latter is a handicap and needs full-time care. Kookie considers Rahman to be a liability and treats him harshly. She directs her servant to provide him less food and drinking water so that Rahman does not have to answer the call of nature more often. Furthermore, Kookie does not like to spend money on Rahman's medicines and other utilities. In a scene, Rehman's diaper needs to be changed, but instead of providing him a new one, Kookie and her servant, Jamil, mistreat Rahman. Following dialogues explains her disrespectful behavior with her handicap father-inlaw, Rehman.

(To Rehman) Lord have mercy! How filthy are you? Shame on you; why don't you tell us beforehand? Can you imagine how costly are these diapers? You would have taken care of at least your son's money if you don't care us. (To Jamil) Now buy him a new pack. (She again yells at Rehman) And this time use the pack throughout a week otherwise you will 
see how I treat you? (To Jamil) And you should reduce his meal and water, too. (Trans. Episode 8, Man Mayal, 2016, 7:29)

Similarly, consider another scene when Salahuddin takes responsibility of taking care of Rehman, Kookie's reaction reveals her inconsiderate behavior. She hides all Rehman's lifesaving drugs just to humiliate Salahuddin; as a result, Rehman suffers and falls unconscious.

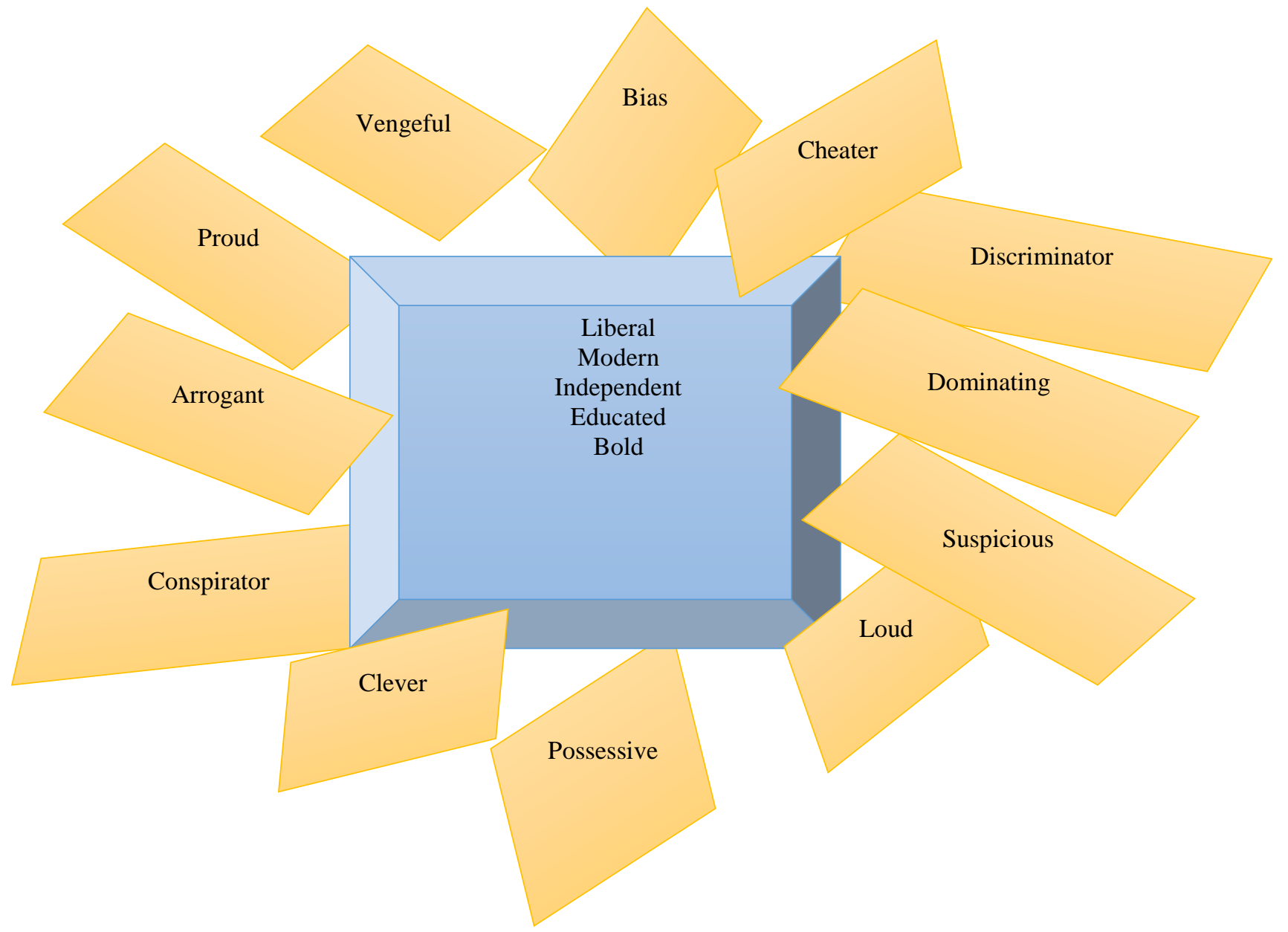

\section{Figure 1: Demographics of Villain Roles}

Let us now consider an example of a negative female role in the drama serial Mere Meherban. Same unkind attitude is reflected through the roles of Shaista and Farida. They both are middle-aged women, dominating and vitriolic in their behaviors. Although they are educated, independent and rich, their rapaciousness and villainy are manifested through their actions. Shaista plays a dominant negative role in this drama. The whole scenario of this drama serial reflects a juxtaposition of the families of two women-Shaista and Nayyara. Both families carry many traditional stereotypical roles. Shaista's family is rich, modern, proud, and rude, while Nayyara's family is poor, humble, supportive and courteous. In the first establishing shot of Shaista, drama director registers many attributes of her personality i.e., middle-aged, graceful, wealthy, modern, and proud lady. The tone of her voice is very aggressive and dominating. In Pakistani society, daughters' weddings are usually finalized with the mutual consent of their parents. But in this drama serial, Shaista appears as a singular deciding authority. Instead of asking the consent of her husband-who works abroad-she only informs him that she has finalized the wedding of their daughter (Episode 1. Mere Meherban, 2014, 3:24). In the same scene the frames of her spacious house, posh outfit, jewelry and nice dresses of her children 
indicate her sound financial position. Following dialogue also reflects the same. The keyword 'designer boutique' also depicts her panache.

Iraj to Shaista (her mother): Engagement ceremony is too close, and we didn't go shopping. Mom, when will we go shopping? When will we go to market?

Shaista: All right, get a grip. In the market, you'll find everything ready. No worries, its matter of hardly an hour. You go to a designer boutique and in an hour you'll come back with your suit (Trans. Episode 1, Mere Meherban, 2014, 4:06).

As Shaista is a typical bighead, arrogant, independent, and disrespectful woman, so are her daughters, Muskan and Iraj. They do not ever show respect and manners to anyone; they rather quarrel and look-down others as well. In the story, their characters' progression as abortive persons, who have failed marital lives, strengthens traditional women stereotyping. The drama also conveys the message that along with other negative attributes, Shaista is incapable of children's civilized grooming. In the drama serial Humsafar, Farida's case is also the same. She performs the role of a vengeful woman, who puts all her efforts to destroy her son's happy married life only because that marriage was against her will. In the last episode of the drama when her son, Ashar, realizes that his mother had been telling lies about his wife and daughter and the reality is totally opposite, he goes in the feelings of repentance and depression. Following dialogues of Ashar endorses Farida's scam and unkind personality who can take any step for her vengeance.

Ashar to Farida (his mother): What kind of love is this? You just killed your son. [You] Proved me sinful in the eyes of the whole world. You turned your son into a faulty and failed person (Trans. Episode 23, Hamsafar, 2012, 1:06).

Ashar to Farida: You wanted to kill my four-year-old daughter (Trans. Episode 23, Hamsafar, 2012, 2:51).

In the last episode of the drama, the flashbacks of Baseerat (Farida's deceased husband), Sara (Ashar's deceased girlfriend) and Khirad (Ashar's wife) confirm Farida's crimes and failure. At the same time, throughout the drama Fradia appears as a wealthy, educated and liberal woman. Her foreign visits, her posh lifestyle, and shots of her outfits depict her sound social and financial status.

\section{Anti-Heroines}

In Pakistani dramas, a trio of traditional love story genre is very common, in which a rich and courteous hero always prefers a submissive, poor, and conservative heroin upon a wealthy, modern and independent girl—who later appears to be a negative character (anti-heroine). The coverage/portrayal of an anti-heroin character depends upon the knitting of a storyline. Sometimes the role of anti-heroin requires more details and extended or frequent shots to portray the complexity of character and her feelings. In this way, the antagonistic roles become more prominent and get popularity among viewers. In my study, anti-heroin characters include Jinna (Man Mayal), Zee (Zid), Asmara (Zindagi Gulzar Hai), and Sara (Hamsafar). All these four roles are predominant antagonists in their pertinent drama. The attributes of these characters display a blend of good and villainy characteristics of their personalities. All these are liberal, modern, progressive and independent females, who know their rights and can fight for them. They are educated, young, and beautiful. Their bold expression and stylish/trendy outfits make them prominent and attractive for everyone; but on the other hand, all these characters also possess negative characteristics of being proud, suspicious, discriminator, cheater, cunning, obsessed, loud, arrogant, and possessive.

Besides these common attributes, Zee (anti-heroin in drama serial Zid) has some unique characteristics. She is portrayed as Pakistani American National who indulges herself in many 
inappropriate and unethical activities like shop-lifting, fighting, etc. Moreover, she spends nights with her boyfriends, badmouths, and consumes drugs and drinks. She is also depicted as a disloyal and untrustworthy person. She is an ex-wife of the hero (Umer). In a scene, while talking to Saman (the second wife of Umer), she admits that Umer is a thorough gentleman and is not responsible for their separation. It was her emotional and extreme attitude that forced her to get divorced. She says: "Everything was perfect. I only wanted him to be emotional, and aggressive. I wanted him to fight with me, yell at me and then say sorry. There must have been some excitement some thrill in our lives" (Trans. Episode 11, Zid, 2015, 31:40). Zee's character holds a dominating aggressive and hostile tendency towards her personality. After getting a divorce from Umer she engages herself in unethical activities. She lives separately, enjoys the company of her passive-aggressive boyfriends and gradually becomes drug addicted and shoplifter. While living a lonely life, she regrets her desire for separation in these words to Saman:

"I don't know why the wrong-ways are so appealing. They were so much shiny and tempting that I didn't see my destination. _ Then I took a wrong turn, then another one, then another. And then I lost" (Trans. Episode 10, Zid, 2015, 4:20).

In a dialogue with Saman, she becomes nostalgic about her past days:

It was really a luxury while I was in my ex-husbands home. It was a huge house, I didn't have to know who and how someone earned money. My only concern was making wishes and demands, and he fulfilled all of them. (Trans. Episode 11, Zid, 2015, 38:42)

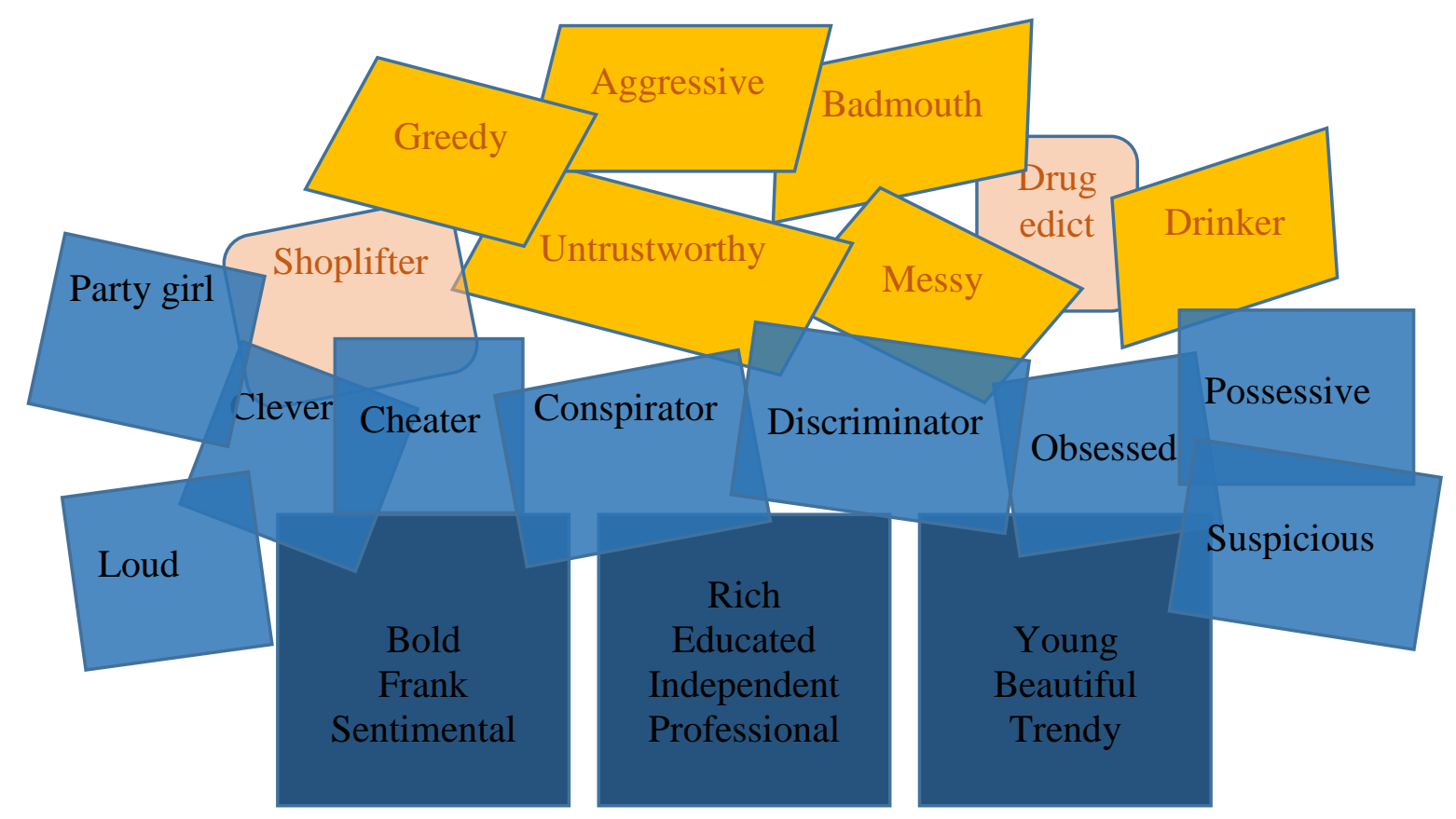

Figure 2: Demographics of Anti-heroines

Zee also reflects the stereotypical impression about independent, liberal, and emotional females that they are always untrustworthy, obsessed, suspicious, emotional, materialistic, and less wise and courteous. The character of Zee strengthens the impression that liberal, bold, aggressive and independent attitude is not acceptable to the male gender. The heroes of the dramas mostly dream about submissive and traditional wives but their dreams do not come true. In the same serial, the heroin, Saman, is also not a typical eastern girl. She possesses bold, independent and egoistic behavior and resultantly she also gets a divorce. Although she is young, beautiful, and well educated, she does not have a compromising and accommodating attitude. So 
her separation also reinforces that she does not qualify as Umer's wife because Umer wants submissive and accommodating life partner.

The same situation can be seen in drama serial Zindagi Gulzar Hay when the hero, Zarun breaks up with Asmara-an independent, rich and modern girl-and gets married with a poor traditionalist Kashaf. In this drama serial, Asmara is showcased as an anti-heroine who is okay as a girlfriend but not suitable as a wife. The drama serial Hamsafar is also a contrast of traditionalism and modernity in which Sara acts as a symbol of modernity versus Khirad who is shown as an eastern traditional woman. Sara is a professional bold and stylish young female. But instead of her frankness with Ashar, the hero (Ashar) chooses an acquiescent and traditional girl, Khirad. Sara is portrayed as a hypersensitive or neurotic female who is obsessed with Ashar's love. After losing his attention she commits suicide, which depicts her emotional instability. Jinna is another anti-heroine role in the drama serial Man Mayal. She is an educated, bold and independent professional woman who wants to marry with Salahuddin (hero of the drama). She tries hard to achieve his love by using different tactics but cannot succeed. This situation also tends to float the idea that the women like Sara, Zee, Jinna, and Asmara are good just for friendship and hanging out but they don't qualify to be wives.

\section{Abortive Persons}

It is expected that a professional female should be equally perfect in household chores because home is considered to be her first responsibility. If she is an unsuccessful mother or wife, but a successful professional, the society does not give her the credit for her contributions (Mumtaz \& Shaheed, 1987). A female character is considered successful only if she performs according to the societal norms. The guage of her success is her domestic and household capability. Consider Wahab (Leading character's uncle)'s misogynistic dialogue here: "These professional women are actually incapable of becoming wives; they have lofty aspirations but in reality they stumble" (Trans. Episode 2, Zindagi Gulzar Hai, 2013, 12:35,) is a crux of prejudice male mentality of Pakistani society. I found many direct and indirect reactionary images and messages in the present study. The negative depiction of six progressive female characters (i.e., Muskan, Iraj, Sara, Zareena, Ghazala and Naeema) as abortive persons endorses a stereotypical women portrayal of Pakistani TV dramas. The above-mentioned six characters are established as independent and forward-looking women. Their visual images show their stylish/ westernized costumes, sleeveless and scarf-less outfits, trendy and lavish belongings, and capacious homes. These all rich, modern, independent and educated female characters end up as failed and abortive persons. The story of Mere Meherban (another popular serial of its time) expresses a common stereotype that these posh females are selfish, greedy and exhibitionists (see Episode 2, Mere Meherban, 23:6) whereas the poor women are humble, hardworking, and genuine (see Episode 4, Mere Meherban, 14:10,). The juxtaposition of rich and poor classes of the society are depicted by the portrayal of two families. The male members of these families are exhibited positively as hardworking, sociable, and straightforward, while all female characters of a rich family (a mother and two daughters) are portrayed negatively. Muskan and Iraj are two sisters and both carry almost same negative attributes like hostile and aggressive attitude, pretentious and materialistic nature, and an egoistic and rude behavior towards others. Finally, both sisters are presented as abortive persons because they fail in their domestic and marital lives. On the other hand, the civilized, well-mannered and submissive women of a poor family get sincere and loving husbands. In the drama serial Zindagi Gulzar Hai, Sara's characterization is not much different from Muskan and Iraj. Sara's husband is a traditional and thorough gentleman who doesn't allow her liberal wife to attend late night parties with her friends. Sara does not want to change her dominating and liberal attitude. Consider the following dialogue:

Sara: I cannot be a typical housewife who waits for her husband on the doorstep.

Farhan: Why? What is wrong with that? 
Sara: Look, throughout my life, I observed that neither my mom asked my dad's permission to go somewhere and nor my dad inquired her repeatedly and made her life a hell.

Farhan: And you think it is right?

Sara: Isn't it? (Trans. Episode 1, Zindagi Gulzar Hai, 2013, 34:25)

Eventually, she gets divorce from her husband but after some time she realizes that getting divorce was a mistake. She blames her mother (Ghazala) for all her failures. Following conversation explains the repentance of Sara and also points to the failure of Ghazala as a mother.

Ghazala: Forget about him [Farhan], he was not a good man.

Sara (sobbing): I don't know whether it was him who wasn't good or me. But I know one thing that you didn't help me at all; you were never there for me.

Ghazala: How can you say that? Why are you accusing me over and over? I didn't pressurize you to get the divorce. It was your own decision and your own stubbornness.

Sara: Okay, you didn't put pressure but you never made me understand, which was your duty as a mother (Trans. Episode 15, Zindagi Gulzar Hai, 2013, 04:31).

In the above-mentioned scene, both characters realize that they have lost the game. There is another female character, Naima who also belongs to an elite family and represents the same negative category. ---- The tropes associated with these negative roles establish a feeling of antipathy for them in the hearts of viewers. Although the negative characters end up in an unsuccessful stage or humiliation, the viewers feel no commiserations for these characters. The thematic study of these characters show some common attributes of this category. If we observe each character's appearance, we find that they are trendy in their outfits. They don't dress conventionally; they all have stylish and trendy costumes. The young female characters occasionally wear jeans and westernized dresses as well.

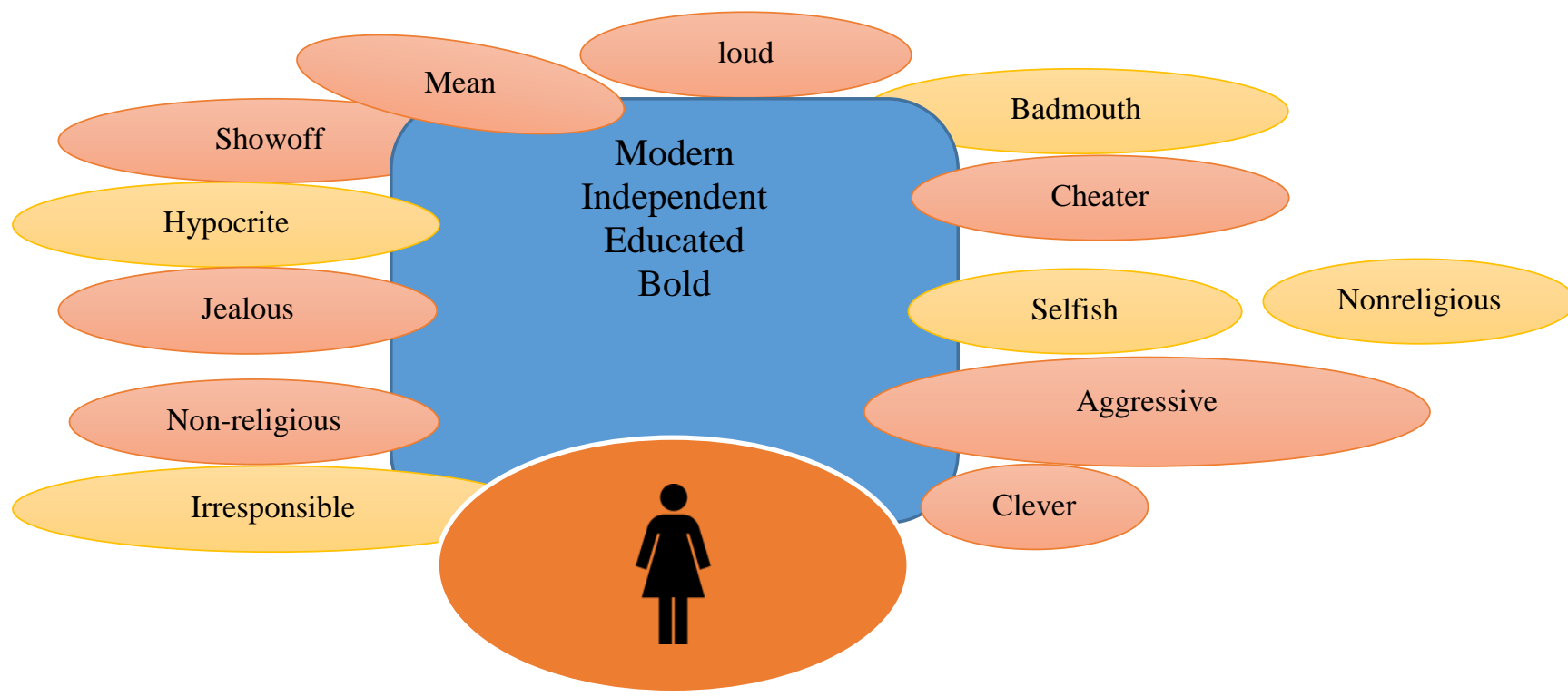

Figure 3: Demographics of Abortive persons 
Figure 3 mentions that all these characters are modern, independent, educated and bold but also have many stereotypical negative labels. Women, presented as unsuccessful mothers, end up being divorced or in few cases suffer from mental depression and isolation. They are depicted as non-religious, egoistic, vengeful, cunning wives/mothers who dominate their husbands. They are fond of extreme liberty and teach the same to their children. Ultimately, children especially girls who follow their footsteps end up with failed married life.

\section{CONCLUSION}

The analysis in this paper manifests that modern Urdu TV drama serials of Pakistan are constantly_albeit implicitly_portraying bold, independent and educated females as villains/anti-heroines or abortive persons. This type of negative female portrayal reinforces stereotypes, which leads toward common misconceptions about all members of the same stratum. In this study of dramas, all three subsets of negative female roles (i.e., villains, anti-heroines, and abortive persons) have a few common positive attributes (i.e., independent, modern and educated). Besides this, every subset has its own attributes i.e., the appearances of all antiheroines are young, charming and beautiful personalities. All mothers are graceful and are active in socialization and community work. But on the other hand, negative stereotyping of being untrustworthy, obsessed, suspicious, and materialistic is associated with them. These modern and independent females are prominently established as emotional, less wise, and less courteous in the dramas. Their boldness, liberal attitude, and modernity are presented as a disqualification for their marital lives. In the comparison of modernity and independent behavior, male protagonists of these dramas always prefer conventional and submissive women for marriage. "Social learning theorists have shown that television and film models, in particular, seem to exert a powerful impact, and one major implication is that television is shaping humans' motivation and behavior on a daily basis." (O'Rorke, 2006, p.73) So by providing a visual demonstration of negative women stereotyping and through the vicarious reinforcement of media messages, these dramas, tend to inspire others to follow the same.

TV dramas are one of the most popular genres of TV shows in Pakistan. Pakistani TV dramas are equally popular in India, Nepal, Bangladesh, and the Middle East. Also, a large number of Pakistani diasporas in UK, USA, Canada, and Norway are also a fan of these drama serials (Boone, 2014; Ghai, 2014; Jaffari, 2014; Shafiq, 2014). In addition to this, the main cast of these dramas has also gained equal popularity. Especially the heroes and heroines have their large fan clubs on social media. These fans try to copy the style of their favorite models in their real life. So one cannot gainsay the vast impact of this popular genre of visual communication.

Conclusively, as my research discusses the ways in which stereotypes are conferred to educated, independent and confident urban women in Pakistani drama serials, I contend that by associating female negative roles with the ideas of modernity, boldness, and liberalism, these drama serials implicitly reinforce conventional and subservient attitudes for women. This archetypal portrayal of women in TV drama serials reduces the prospects of diversity, openness, and acceptance of an independent and progressive approach of women in Pakistan. Finally, this research is significant for studying the problems of media portrayal for women in Pakistan-a country wherein women belong to the marginalized and underrepresented section of the society. The study of effects-albeit not the main focus of this paper-is crucial to determine how these stereotypes, circulated by Pakistani TV dramas-are affecting the women behavior in Pakistan.

\section{REFERENCES}

Aslam, I. \& Ali, K. A. (2009). Media Matters in Pakistan. Middle East Report, 251,32-36.

Bandura, A. (1971). Social Learning Theory. General Learning Press, 79 Madison Avenue New York, NY.

Bandura, A. (1977). Social learning theory. Englewood Cliffs, NJ: Prentice-Hall. 
Bandura, A. (2009). Social cognitive theory of mass communication. In J. Bryant \& M. B. Oliver (Eds.), Media effects: Advances in theory and research (2nd ed., pp. 94-124). Mahwah, NJ: Lawrence Erlbaum.

Boone, J. (2014, June 23). Indians to get peek into daily lives of Pakistanis with new soap opera channel. The Guardian. Retrieved from https://www.theguardian.com/world/2014/jun/23/indian-tvchannel-show-pakistani-soaps

Coll, S. (2009). On the Grand Trunk Road. New York, NY: Penguin Books

Collins, R. (2011). Content analysis of gender roles in media: Where are we now and where should we go? Sex Roles 64, 290-298.

Conflict. (n.d.). In Dictionary.com online. Retrieved from http://www.dictionary.com/browse/conflict?s=t

Conflict. (n.d.). In Marriam Webster online. Retrieved from https://www.merriamwebster.com/dictionary/conflict?src=search-dict-hed

Coombo, J. \& Davis, S. N. (2013). Gender differences in the influence of television on gender ideology? TV hours and attitudes toward employed mothers 1988-2008. International Review of Modern Sociology, 39 (2), 205-223.

Daalmans, H. \& Wester (2014) 'One Night of Prime Time': An Explorative Study of Morality in One Night of Prime Time Television, Journal of Mass Media Ethics, 29:3, 184-199, DOI: 10.1080/08900523.2014.918498

Fernea, Elizabeth Warnock (1998). In Search of Islamic Feminism: One Woman's Global Journey. New York, Anchor Books.

Gerbner, G. (1998). Cultivation analysis: An overview. Mass Communication \& Society, 1(3/4), 175-194.

Gerbner, G. \&Signorielli, N. (1979). Women and minorities in television drama 1969-1978. Philadelphia: The Annenberg School of Communication, University of Pennsylvania.

Ghai, S. (2014, July 13). [Twitter post] Retrieved from https://twitter.com/SubhashGhai1/statuses/488218487819874304

Gul, S. (2017, August 29). Stereotypical portrayal of women in media. Daily Times. Retrieved from https://dailytimes.com.pk/118909/stereotypical-portrayal-of-women-in-media/

Haider, S. (2017 March 10). TV drama San-e-Marmar is a necessary critique of Pakistan's obsession with 'ghairat'. Images. Retrieved from https://images.dawn.com/news/1177229

Hasan, B. (2000). Uncensored: An eyewitness account of abuse of power and media in Pakistan. Karachi, Pakistan: Royal Book Company.

Hassan, H. (Director), \& Fazal, S. (Writer). (2016). Episode 8 [MP4]. In Duraid, M. (Producer), Man Mayal. Pakistan: Hum TV

Hermes (2007, P.191) mentioned in (McQuail Theories of Mass Communication).

Hussain, N. (1996). Television Drama. In M. Malik, \& N. Hussain (Eds.), Reinventing Women: Representation of Women in the Media During the Zia Years (pp. 22- 42). Lahore, Pakistan: Simorgh Women's Resource and Publication Centre.

Jafri, K. (Director), Gul, B.(Writer). (2014). Zid, Pakistan: Hum TV

Khoosat, S. (Director), Ishtiaq, F. (Writer). (2012). Hamsafar, Pakistan: Hum TV

Kothari, S. (2005). From genre to zanaana: Urdu television drama serials and women's culture in Pakistan. Contemporary South Asia, 14 (3), 289-305.

Mansoor, Z. (2010). Print Media Language: A Contributing Factor in Setereotypical Portrayal of Pakistani Women, VDM Verlag, Dr. Muller.

McNeil, (1975). Feminism, femininity, and the television series: A content analysis. Journal of Broadcasting, 19(3), 259-271

Mumtaz \& Shaheed (1987). Women of Pakistan: Two Steps Forward, One Step Back? London, Zed Books Ltd.

O'Rorke, K. (2006). Social learning theory and mass communication. ABEA Journal, 25, 72-74.

Pehlke, T., Hennon, C., Radina, M., Kuvalanka, K. (2009). Does Father still know best? An inductive thematic analysis of popular TV sitcoms. Fathering 7(2), 114-139.

Raman, P., Harwood, J., Weis, D., Anderson, J. L., Miller, G. (2008). Portrayals of older adults in US and Indian magazine advertisements: A cross-cultural comparison. The Howard Journal of Communications. 19 (3): 221-240.

Riddle, K. E. , 2009-05-21 "Cultivation Theory Revisited: The Impact of Childhood Television Viewing Levels on Social Reality Beliefs and Construct Accessibility in Adulthood" Paper presented at the annual meeting of the International Communication Association, Marriott, Chicago, IL Online <PDF>. 2017-09-11 from http://citation.allacademic.com/meta/p299457_index.html 
Rind, F. (Director), Malik, M. (Writer). (2014). Mere Meherban, Pakistan: Hum TV

Saeed, M. (2016, September 21). Pakistani soap to break stereotypes with Christian protagonist. The Express Tribune. Retrieved from https://tribune.com.pk/story/1185928/pakistani-soap-breakstereotypes-christian-protagonist/

Shafiq, M. (2014, January 10). Pakistani Dramas take the Arab World by storm - ZGH to be dubbed in Arabic now. [Web log article]. Retrieved from http://reviewit.pk/pak-dramas-take-the-arab-worldby-storm-zgh-to-be-dubbed-in-arabic-now/

Shah, Iqtidar Ali; Aziz, Arshad; and Ahmad, M. Shakil (2015). Women Councilors for Women's

Empowerment in Pakistan. Journal of International Women's Studies, 16(3), 203-219. Available at: http://vc.bridgew.edu/jiws/vol16/iss3/14

Siddiqui, S. (Director), Ahmad, U. (Writer). (2014). Zindagi Gulzar Hai, Pakistan: Hum TV

Smith, S. (2016). The data behind Hollywood's sexism, TEDWomen, Retrieved from https://www.ted.com/talks/stacy_smith_the_data_behind_hollywood_s_sexism/up-next

Talib, S. \& Idrees, Z. (2012). Pakistani media and disempowerment of women. In Carilli, T. \& Campbell, J. (Eds.), Challenging Images of Women in the Media: Reinventing Women's Lives (27 - 34) Lanham, Maryland: Lexington Books.

World Economic Forum. (2017). The Global Gender Gap Report 2017. Switzerland, Geneva: Schwab, K., Samans, R., Zahidi, S., Leopold, T. A., Ratcheva, V.

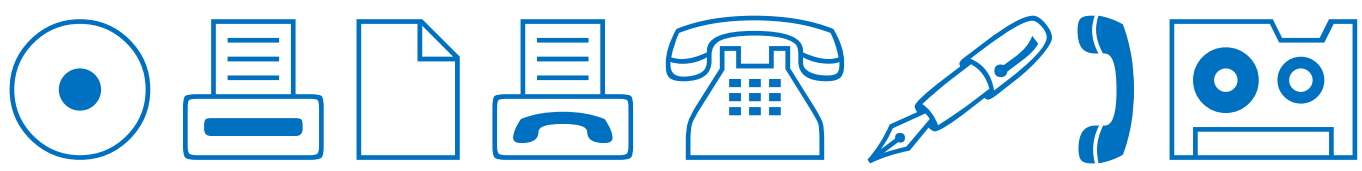

